\title{
Ranking of developing countries Based on the Economic Freedom Index
}

\author{
Mohsen Mehrara ${ }^{1, *}$, Masoumeh Zirak ${ }^{2, * *}$ \\ ${ }^{1}$ Faculty of Economics, University of Tehran, \\ Kargar-e-shomali, Po Box: 14166-6445, Postal code: 1411734115, Tehran, Iran \\ Tel: $+98-88029007$ \\ ${ }^{2}$ M.A in Economics, International Campus-Kish Island, University of Tehran, Tehran, Iran \\ *,**E-mail address: mmehrara@ut.ac.ir, masoumeh.zirak@ut.ac.ir
}

\begin{abstract}
In this paper we've ranked developing countries based on the Economic Freedom index. Therefore we are trying to do the analysis how this ranking is done using numerical taxonomic methodology. To do this, by estimating the effects of the determinants of FDI in 123 developing countries from 1997 to 2010 , results showed that with regard to the degree of economic freedom or Economic openness, attract foreign direct investment in each country is different. In this study china, Equator, Liberia, Azerbaijan, Angola, Turkmenistan, Cape Verde, Kazakhstan, Panama, Vietnam, Bulgaria, Congo, Maldives, Bahrain, Cambodia, Jordan, Malaysia, Mongolia, Sudan, Trinidad, Belarus, Lesotho, Russian are the top 23 countries have been successful in attracting foreign direct investment thanks to appropriate economic and structures policies.
\end{abstract}

Keywords: Developing countries; FDI; Economic Freedom; Numerical Taxonomy

JEL Classification: F21, M21, P33

\section{INTRODUCTION}

The Index of Economic Freedom is a series of 10 economic measurements created by the Heritage Foundation and Wall Street Journal. The Index's definition of economic freedom is the following; "Economic freedom is the fundamental right of every human to control his or her own labor and property. In an economically free society, individuals are free to work, produce, consume, and invest in any way they please, with that freedom both protected by the state and unconstrained by the state. In economically free societies, governments allow labor, capital and goods to move freely, and refrain from coercion or constraint of liberty beyond the extent necessary to protect and maintain liberty itself. The index scores nations on 10 broad factors of economic freedom using statistics from organizations like the World Bank, the International Monetary Fund and the Economist Intelligence Unit:

- Business freedom

- Trade freedom

- Monetary freedom

- Government size

- Fiscal freedom

- Property rights

- Investment freedom 
- Financial freedom

- Freedom from corruption

- Labor freedom

The 10 factors are averaged equally into a total score.

Business Freedom: Business freedom is a quantitative measure of the ability to start, operate, and close a business that represents the overall burden of regulation as well as the efficiency of government in the regulatory process.

Trade Freedom: Trade freedom is a composite measure of the absence of tariff and non-tariff barriers that affect imports and exports of goods and services. Different imports entering a country can, and often do, face different tariffs.

Monetary Freedom: Monetary freedom combines a measure of price stability with an assessment of price controls. Both inflation and price controls distort market activity. Price stability without microeconomic intervention is the ideal state for the free market.

Government Size/Spending: This component considers the level of government expenditures as a percentage of GDP. Government expenditures, including consumption and transfers, account for the entire score.

Fiscal Freedom: Fiscal freedom is a measure of the tax burden imposed by government.

Property Rights: The property rights component is an assessment of the ability of individuals to accumulate private property, secured by clear laws that are fully enforced by the state.

Investment Freedom: In an economically free country, there would be no constraints on the flow of investment capital. Individuals and firms would be allowed to move their resources into and out of specific activities internally and across the country's borders without restriction.

Financial Freedom: Financial freedom is a measure of banking efficiency as well as a measure of independence from government control and interference in the financial sector.

Freedom from Corruption: Corruption erodes economic freedom by introducing insecurity and uncertainty into economic relationships. The higher the level of corruption, the lower the level of overall economic freedom and the lower a country's score.

Labor Freedom: The labor freedom component is a quantitative measure that looks into aspects of the legal and regulatory framework of a country's labor market.

However, a number of indicators of economic freedom have been proposed. They differ in the methods by which they have been constructed, the purposes to which they have been put and the conception of economic freedom they embody.

The foundations of economic freedom are personal choice, voluntary exchange, and open markets. As Adam Smith, Milton Friedman, and Friedrich Hayek have stressed, freedom of exchange and market coordination provide the fuel for economic progress. Without exchange and entrepreneurial activity coordinated through markets, modern living standards would be impossible.

After introducing the economic freedom index, we ranked countries according to the Index of Economic Freedom. A ranking of countries or states based on the number and intensity of government regulations on wealth-creating activity. Metrics that an economic freedom index evaluates include international trade restrictions, government spending relative to GDP, occupational licensing requirements, private property rights, minimum wage laws 
and other government-controlled factors that affect people's ability to earn a living and keep what they earn. Such indexes are usually produced by economic think tanks ${ }^{1}$.

There are several non-governmental organizations that publish and maintain assessments of the state of freedom in the world, according to their own various definitions of the term, and rank countries as being free, partly free, or unfree using various measures of freedom, including political rights, economic rights, and civil liberties.

In this part, we are trying to do the analysis how this ranking is done using numerical taxonomic methodology. Indeed Numerical taxonomy analysis is one of the best methods of grading, classifying and comparing countries or different regions according to their development levels and modernity, that it can be used for different grading too.

\section{RESEARCH METHODOLOGY}

The Numerical Taxonomy that first was proposed by Adamson in 1763 was developed by Polish mathematician in the early 1950s. Hell Wing offered this method to UNESCO ${ }^{2}$. Capabilities of this method lead to its being employed in economics, social, agricultural and medical sciences to name a few.

Today the Numerical Taxonomy is employed for activities, economic sectors, towns, regions, countries ranking with respect to several different or sometimes contrasting economic and social factor indices. There are many evidences in implementation of this method in the entire world. The ranking process of countries by this method is carried on through several stages, generally explained with a bit of variation in different resources:

The first stage is related to data matrix formation, matrix $X$, in which $\mathrm{x}$ shows the elements of the $i, j$ matrix. In this study, $i$ stand on the rows of the matrix, pertaining to the countries. The columns of this matrix relates to the indices. Thus, for ranking the developing countries with respect to 7 indices, the data matrix has 123 rows and 7 columns.

The second stage is related to standardization of the primary data that are measured with different units. To eliminate the effect of such disparity, matrix Z, the standard matrix of $\mathrm{X}$ is calculated as follows:

$$
\begin{aligned}
& E(X)=\left(\left(\sum_{i=1}^{123} X i j\right) / 123\right) \\
& S j=\sqrt{\left(\sum_{i=1}^{123}(X i j-E(X))^{2}\right) / 123} \\
& Z i j=(\mathrm{Xij}-\mathrm{E}(\mathrm{X})) / \mathrm{Sj}
\end{aligned}
$$

$E(x)$ stands on the average of different indices, $s_{j}$ the standard error, $z$ the elements of $Z$. To test the homogeneity of the countries, the distance matrix of indices for countries from each other is calculated in the third stage. This matrix that is yielded through equation (4) is a symmetric matrix. Since the indices of countries from itself, it is equal to zero.

1. An economic think tank is an organization whose mission it is to study and reflect on economic issues. Economic think tanks are essentially economic policy institutes that work to develop and propose economic strategies and policies to benefit the overall economy. Economic think tanks can be privately funded, and as such can be under scrutiny for being biased towards the needs or special interests of the donor(s).

2. United Nations Educational, Scientific and Cultural Organization (UNESCO) 
$d_{a b}=\sum_{i=1}^{7}\left(z_{a j}-Z_{b j}\right)^{2}$

Thus, $\mathrm{d}_{a, b}$ shows the standardized indices of country a from country $\mathrm{b}$. With respect to the results of the third stage, the limits of homogeneity of the countries are calculated. To this end, the shortest distance vector is made from the smallest elements of distance matrix rows:

$$
\begin{aligned}
& \mathrm{D}=\min [\mathrm{dij}]=[\mathrm{d} 1, \mathrm{~d} 2, \ldots, \mathrm{dn}], \mathrm{j}=1,2, \ldots . .7, \mathrm{j} \neq \mathrm{i} \\
& E(d)=\left(\left(\sum_{i=1}^{123} d i\right) / 123\right) \\
& \boldsymbol{S}_{d}=\sqrt{\left(\sum_{i=1}^{123}(d i-E(d))^{2}\right) / 123} \\
& \mathrm{~d} 1=E(d)-2 S_{d}, d 2=E(d)-2 S_{d}
\end{aligned}
$$

In the fourth stage $D$ denotes the vector that contains the shortest distance, $E(d)$ and $S_{d}$ the average and standard error of $d_{i}$ elements of vector $D$, respectively and finally $L_{1}$ and $\mathrm{L}_{2}$ the up and down limits of homogeneity domain of the countries, respectively. Countries that have shorter distance with the other ones are in this domain. Those countries which are homogenous can be compared with each other, with respect to the concerned indices.

The fifth stage pertains ranking among the homogenous countries. To this end, a standard matrix is calculated for the homogenous countries. To rank the countries with respect to related indices, the maximum value of columns is selected as the ideal value (relationship (9)). Using the relationship (10), the distance of the countries is calculated from the ideal value of the countries is calculated from ideal value of the columns.

$$
\begin{aligned}
& \mathrm{Z}_{\mathrm{mj}}=\operatorname{Max}(Z i j, i=1,2, \ldots, n) \\
& d_{i m}=\sqrt{\left(\sum_{i=1}^{7}(Z i j-Z m i)^{2}\right.}
\end{aligned}
$$

$\mathrm{Z}_{\mathrm{mj}}$ refers to the maximum value of index $\mathrm{j}$ and $\mathrm{d}_{\mathrm{im}}$ the distance of the $\mathrm{i}^{\text {th }}$ country from the ideal value for indices. A smaller value for $\mathrm{d}_{\text {im }}$ indicates that the country has less distance from the ideal value of indices and as a result, is located in a better rank. Thus the countries are ranked based on these distances.

The results of Table show that; China, Equator, Liberia, Azerbaijan, Angola, Turkmenistan, Cape Verde, Kazakhstan, Panama, Vietnam, Bulgaria, Congo, Maldives, Bahrain, Cambodia, Jordan, Malaysia, Mongolia, Sudan, Trinidad, Belarus, Lesotho, Russian are the top 23 countries have been successful in attracting foreign direct investment thanks to appropriate economic and structures policies. Therefore, we can say with regard to the degree of Economic openness, attract foreign direct investment in each country is different. 
Table1. Ranking of developing countries Based on the index of Economic Freedom.

\begin{tabular}{|c|c|c|c|c|c|c|c|c|c|c|c|c|}
\hline & Rank & $\begin{array}{l}\text { Ranking } \\
\text { standard }\end{array}$ & Countries & Row & Rank & $\begin{array}{l}\text { Ranking } \\
\text { standard }\end{array}$ & Countries & Row & Rank & $\begin{array}{l}\text { Ranking } \\
\text { standard }\end{array}$ & Countries & Row \\
\hline & 13 & 0.84 & Tunisia & 43 & 10 & 0.81 & Lesotho & 22 & 1 & 0.54 & China & 1 \\
\hline & 14 & 0.85 & Brazil & 44 & 10 & 0.81 & Russian & 23 & 2 & 0.63 & Equator & 2 \\
\hline 14 & & 0.85 & Lao PDR & 45 & 11 & 0.82 & Bosnia a & 24 & 3 & 0.68 & Liberia & 3 \\
\hline 14 & & 0.85 & Mauritius & 46 & 11 & 0.82 & Chad & 25 & 4 & 0.7 & Azerbaijan & 4 \\
\hline 14 & & 0.85 & Ukraine & 47 & 11 & 0.82 & Chile & 26 & 5 & 0.73 & Angola & 5 \\
\hline 14 & & 0.85 & Zambia & 48 & 11 & 0.82 & India & 27 & 6 & 0.75 & Turkmenistan & 6 \\
\hline & 15 & 0.86 & Egypt & 49 & 11 & 0.82 & Thailand & 28 & 7 & 0.77 & Cape Ver. & 7 \\
\hline 15 & & 0.86 & Gambia & 50 & 12 & 0.83 & Belize & 29 & 7 & 0.77 & Kazakhstan & 8 \\
\hline 15 & & 0.86 & Ghana & 51 & 12 & 0.83 & Botswana & 30 & 7 & 0.77 & Panama & 9 \\
\hline 15 & & 0.86 & Guyana & 52 & 12 & 0.83 & Georgia & 31 & 7 & 0.77 & Vietnam & 10 \\
\hline 15 & & 0.86 & Kyrgyz R & 53 & 12 & 0.83 & Lithuania & 32 & 8 & 0.79 & Bulgaria & 11 \\
\hline 15 & & 0.86 & Namibia & 54 & 12 & 0.83 & Mexico & 33 & 8 & 0.79 & Congo & 12 \\
\hline 15 & & 0.86 & Philippi & 55 & 12 & 0.83 & Switzerland & 34 & 8 & 0.79 & Maldives & 13 \\
\hline 15 & & 0.86 & Uganda & 56 & 12 & 0.83 & Tajikistan & 35 & 9 & 0.8 & Bahrain & 14 \\
\hline & 16 & 0.87 & Albania & 57 & 13 & 0.84 & Armenia & 36 & 9 & 0.8 & Cambodia & 15 \\
\hline 16 & & 0.87 & Bahamas, & 58 & 13 & 0.84 & Costa Rica & 37 & 9 & 0.8 & Jordan & 16 \\
\hline 16 & & 0.87 & Bolivia & 59 & 13 & 0.84 & Dominica & 38 & 9 & 0.8 & Malaysia & 17 \\
\hline 16 & & 0.87 & Ethiopia & 60 & 13 & 0.84 & Honduras & 39 & 9 & 0.8 & Mongolia & 18 \\
\hline 16 & & 0.87 & Kuwait & 61 & 13 & 0.84 & Latvia & 40 & 9 & 0.8 & Sudan & 19 \\
\hline 16 & & 0.87 & Macedonia & 62 & 13 & 0.84 & Mozambique & 41 & 9 & 0.8 & Trinidad & 20 \\
\hline 16 & & 0.87 & Mauritania & 63 & 13 & 0.84 & Saudi Arabia & 42 & 10 & 0.81 & Belarus & 21 \\
\hline
\end{tabular}


Table 1 (continue). Ranking of developing countries Based on the Economic Freedom.

\begin{tabular}{|c|c|c|c|c|c|c|c|c|c|c|c|}
\hline Rank & $\begin{array}{l}\text { Ranking } \\
\text { standard }\end{array}$ & countries & Row & Rank & $\begin{array}{l}\text { Ranking } \\
\text { standard }\end{array}$ & countries & Row & Rank & $\begin{array}{l}\text { Ranking } \\
\text { standard }\end{array}$ & countries & Row \\
\hline 21 & 0.92 & El Salvador & 106 & 19 & 0.9 & Afghanis & 85 & 16 & 0.87 & Nicaragua & 64 \\
\hline 21 & 0.92 & Iran, Is & 107 & 19 & 0.9 & Algeria & 86 & 16 & 0.87 & Nigeria & 65 \\
\hline 21 & 0.92 & Jamaica & 108 & 19 & 0.9 & Barbados & 87 & 16 & 0.87 & Papua Ne & 66 \\
\hline 21 & 0.92 & Kenya & 109 & 19 & 0.9 & Colombia & 88 & 16 & 0.87 & Peru & 67 \\
\hline 21 & 0.92 & Yemen, R & 110 & 19 & 0.9 & Ecuador & 89 & 16 & 0.87 & Sri Lank & 68 \\
\hline 22 & 0.93 & Burkina & 111 & 19 & 0.9 & Guatemala & 90 & 16 & 0.87 & Tanzania & 69 \\
\hline 22 & 0.93 & Niger & 112 & 19 & 0.9 & Libya & 91 & 17 & 0.88 & Argentine & 70 \\
\hline 23 & 0.94 & Tonga & 113 & 19 & 0.9 & Malawi & 92 & 17 & 0.88 & Bangladesh & 71 \\
\hline 24 & 0.96 & Haiti & 114 & 19 & 0.9 & Pakistan & 93 & 17 & 0.88 & Djibouti & 72 \\
\hline 24 & 0.96 & Kiribati & 115 & 19 & 0.9 & Serbia & 94 & 17 & 0.88 & Indonesia & 73 \\
\hline 25 & 0.97 & Bermuda & 116 & 19 & 0.9 & Sierra L & 95 & 17 & 0.88 & Mali & 74 \\
\hline 25 & 0.97 & Comoros & 117 & 19 & 0.9 & South Africa & 96 & 17 & 0.88 & Morocco & 75 \\
\hline 25 & 0.97 & Timor-Le & 118 & 20 & 0.91 & Cameroon & 97 & 17 & 0.88 & Paraguay & 76 \\
\hline 26 & 0.98 & Burundi & 119 & 20 & 0.91 & Gabon & 98 & 17 & 0.88 & Romania & 77 \\
\hline 26 & 0.98 & Suriname & 120 & 20 & 0.91 & Guinea & 99 & 17 & 0.88 & Syrian A & 78 \\
\hline 27 & 1 & Guinea-B & 121 & 20 & 0.91 & Madagascar & 100 & 17 & 0.88 & Turkey & 79 \\
\hline 28 & 1.01 & Zimbabwe & 122 & 20 & 0.91 & Nepal & 101 & 18 & 0.89 & Fiji & 80 \\
\hline \multirow[t]{4}{*}{29} & 1.02 & Micronesia & 123 & 20 & 0.91 & Togo & 102 & 18 & 0.89 & Montenegro & 81 \\
\hline & & & & 20 & 0.91 & Uruguay & 103 & 18 & 0.89 & Senegal & 82 \\
\hline & & & & 21 & 0.92 & Benin & 104 & 18 & 0.89 & Uzbekistan & 83 \\
\hline & & & & 21 & 0.92 & Congo, & 105 & 18 & 0.89 & Venezuela & 84 \\
\hline $\begin{array}{l}\text { Source } \\
\text { Note: } r\end{array}$ & $\begin{array}{l}\text { omputing } r \\
\text { data from; }\end{array}$ & $\begin{array}{l}\text { earch (DATA } \\
\text { ta.worldbank }\end{array}$ & $\begin{array}{l}97-20 \\
g / d a t\end{array}$ & atalog & orld-develc & ent-indicator & & & & & \\
\hline
\end{tabular}

Table 2. Grouping of developing countries based on the rank of Economic Freedom.

\begin{tabular}{c|c|l}
\hline Groups & Rank & \multicolumn{1}{c}{ Countries } \\
\hline 1 & $1-6$ & $\begin{array}{l}\text { China, Equatorial Guinea, Liberia, Azerbaijan, Angola, Turkmenistan } \\
\text { Cape Verde, Kyrgyzstan, Panama, Vietnam, Bulgaria, Democratic Congo, Maldives, } \\
\text { Bahrain, Cambodia, Jordan, Malaysia, Mongolia, Sudan, Trinidad and Tobago, Belarus, } \\
\text { Lesotho, Russia } \\
\text { Bosnia, Chad, Chile, India, Thailand, Belize, Botswana, Georgia, Lithuania, Mexico, } \\
\text { Switzerland, Tajikistan, Armenia, Costa Rica, Dominican, Honduras, Latvia, Mozambique, } \\
\text { Saudi Arabia, Tunisia, Brazil, Laos, Mauritius, Ukraine, Zambia, Egypt, Gambia, Ghana, } \\
\text { Guyana, Kyrgyzstan, Namibia, the Philippines, Uganda } \\
\text { Albany, The Bahamas, Bolivia, Ethiopia, Kuwait, Macedonia, Mauritania, Nicaragua, } \\
\text { Nigeria, Papua, Peru, Syrlanka, Tanzania, Argentina, Bangladesh, Djibouti, Indonesia, } \\
\text { Mali, Morocco, Paraguay, Romania, Syria, Turkey, Fiji, Montenegro Senegal, Uzbekistan, } \\
\text { Venezuela } \\
\text { Afghanistan, Algeria, Barbados, Colombia, Ecuador, Gvtmala, Libya, Malawi, Pakistan, } \\
\text { Serbia, Siri Alyvn, South Africa, Cameroon, Gabon, Guinea, Madagascar, Nepal, Togo, } \\
\text { Uruguay } \\
\text { Benin, Republic of Congo, El Salvador, Iran, Jamaica, Kina, Niger, Tonga, Haiti, Kiribati, } \\
\text { Yemen, Burkina Faso, Bermuda, Comoros, Timor, Burundi, Suriname, Guinea-Bissau, } \\
\text { Zimbabwe, Micronesia. }\end{array}$ \\
\hline
\end{tabular}

Source: Computing research 


\section{SUMMARY AND CONCLUSION}

Because of the importance of economic freedom in attracting foreign investment, we have studied the conditions in order to attract foreign investment in developing countries. This issue examined with economic freedom indexes and countries were ranked using a Numerical Taxonomy. Results showed that China, Equator, Liberia, Azerbaijan, Angola, Turkmenistan, Cape Verde, Kazakhstan, Panama, Vietnam, Bulgaria, Congo, Maldives, Bahrain, Cambodia, Jordan, Malaysia, Mongolia, Sudan, Trinidad, Belarus, Lesotho, Russian are the top 23 countries have been successful in attracting foreign direct investment thanks to appropriate economic and structures policies. But in countries such as Benin, Republic of Congo, El Salvador, Iran, Jamaica, Kina, Niger, Tonga, Haiti, Kiribati, Yemen, Burkina Faso, Bermuda, Comoros, Timor, Burundi, Suriname, Guinea-Bissau, Zimbabwe, Micronesia foreign investment is extraordinary low.

The most important barriers appear to be such as Oil-dependent economy, Economic sanctions, excessively complex administrative procedures, required to establish, and operate a business, the delays associated with securing land access, and obtaining building permits, etc.

\section{APPENDIX: A LIST OF THE COUNTRIES STUDIED}

Afghanistan, Albania, Algeria, Angola, Argentina, Armenia, Azerbaijan, Bahamas, Bahrain, Bangladesh, Barbados, Belarus, Belize, Benin, Bermuda, Bolivia, Bosnia and Herzegovina, Botswana, Brazil, Bulgaria, Burkina Faso, Burundi, Cambodia, Cameroon, Cape Verde, Chad, Chile, China, Colombia, Comoros, Democratic Congo, Republic of the Congo, Costa Rica, Djibouti, Dominican Republic, Ecuador, Egypt, El Salvador, Equatorial Guinea, Ethiopia, Fiji, Gabon, Gambia, Georgia, Ghana, Guatemala, Guinea , Guinea Bissau, Guyana, Haiti, Honduras, India, Indonesia, Iran, Jamaica, Jordan, Kazakhstan, Kenya, Kiribati, Kuwait, Kyrgyz Republic, Laos, Latvia, Lesotho, Liberia, Libya, Lithuania, Macedonia, Madagascar, Malawi, Malaysia , Maldives, Mali, Mauritania, Mauritius, Mexico, Micronesia, Mongolia, Montenegro, Morocco, Mozambique, Namibia, Nepal, Nicaragua, Niger, Nigeria, Pakistan, Panama, Papua, New Guinea, Paraguay, Peru, Philippines, Romania, Russia, Saudi Arabia, Senegal, Serbia, Sierra Leone, South Africa, Sri Lanka, Sudan, Suriname, Switzerland, Syria, Tajikistan, Tanzania, Thailand, Timor, Togo, Tonga, Trinidad and Tobago, Tunisia, Turkey, Turkmenistan, Uganda, Ukraine, Uruguay, Uzbekistan, Venezuela, Vietnam, Yemen, Zambia, Zimbabwe.

\section{References}

[1] World Survey of Economic Freedom 1995-1996: A Freedom House Study. Transaction Publishers. 1996. ISBN 978-1-56000-929-0. p. 5-7.

[2] http://www.heritage.org/Index/FAQ.aspx.Retrieved 2009-01-25.

[3] http://en.wikipedia.org/w/index.php?title=Indices_of_economic_freedom\&oldid= 492112903

[4] http://www.investopedia.com/terms/i/index-of-economic-freedom.

[5] http://www.cato.org. 